\author{
The

\title{
Histological and histochemical studies of Sweatgland in crossbreed cattle
}

\section{P.J. Kapadnis and P.N.Thakur}

Author for Corresponding -

\section{P.N. Thakur}

Department of Veterinary

Anatomy and Histology

College of Veterinary and Animal

Sciences, Parbhani (M.S.)

India
ABSTRACT..... The sweat glands were apocrine type of glands present at the deeper part of the dermis. These glands were found oval and rounded in heifer, elongated oval and spherical arranged in clustures in lactating cow and elongated and tubular with narrow lumen in pregnant cow and were lined by simple cuboidal epitherlical cells.

KEY WORDS...... Histology, Histochemistery, Sweat gland, Crossbreed, Cattle

HOW TO CITE THIS ARTICLE - Kapadnis, P.J. and Thakur, P.N. (2018). Histological and histochemical studies of Sweatgland in crossbreed cattle. Asian J. Animal Sci., 13(2): 82-85. DOI : 10.15740/HAS/ TAJAS/13.2/82-85. Copyright@2018:HindAgri-Horticultural Society.

ARTICLE CHRONICLE - Received : 27.08.2018; Revised : 15.11.2018; Accepted : 26.11.2018 